\title{
PREVALENSI KARIES GIGI MOLAR SATU PERMANEN PADA SISWA SEKOLAH DASAR USIA 8-10 TAHUN
}

\author{
Ninis Yekti Wulandari*, Tiara Fahriliyandi Putri**, Vicka Amalia**, Wilda Rahmadhianie** \\ *Puskesmas Kelurahan Pasar Minggu 1, Jakarta \\ **Fakultas Kedokteran Gigi, Universitas Prof. Dr. Moestopo (Beragama), Jakarta \\ Korespondensi: Vicka Amalia, vickaamalia1603@gmail.com
}

\begin{abstract}
ABSTRAK
Latar belakang: karies gigi merupakan salah satu gangguan kesehatan gigi dan mulut. Gigi molar satu merupakan gigi tetap yang pertama erupsi pada umur sekitar 6-7 tahun, sehingga menjadi gigi yang paling berisiko terkena karies. Prevalensi karies gigi molar satu permanen pada anak umur $8-10$ tahun merupakan jumlah orang dalam satu populasi yang mengalami karies gigi. Tujuan: tujuan penelitian ini untuk mengetahui prevalensi karies gigi molar satu permanen pada anak umur 8 - 10 tahun dilakukan di SDN 04 Pagi Pasar Minggu, SDN 05 Pagi Pasar Minggu, SD AlHikmah dan MI Darul Mutaqqin pada bulan Oktober 2018. Metode: jenis penelitian yang digunakan adalah deskriptif observasional. Populasi pada penelitian ini adalah semua anak sekolah usia 8-10 tahun. Metode pengambilan sampel yang digunakan yaitu purposive sampling. Hasil: data hasil pemeriksaan karies gigi molar satu permanen pada anak umur 8 - 10 tahun diperoleh melalui pemeriksaan karies yang bersifat objektif. Pada 236 sampel terdapat 944 gigi molar satu permanen dan hasil penelitian menunjukkan gigi yang mengalami karies sebanyak 108 gigi pada anak umur 8 tahun, 233 gigi pada anak umur 9 tahun dan 137 gigi pada anak umur 10 tahun. Kesimpulan: berdasarkan hasil penelitian yang telah dilakukan dapat disimpulkan penyebab karies gigi masih tinggi adalah kurangnya pemahaman dan kesadaran dalam pemeliharaan kesehatan gigi dan mulut baik dari anak dan orangtua.
\end{abstract}

Kata kunci: prevalensi, molar satu permanen, anak usia 8-10 tahun

\section{ABSTRACT}

Background: dental caries is one of oral health problems. First molar is the permanent teeth that first erupted at around $6-7$ years old, so it can be the most at risk for caries. The prevalence of first molar permanent caries in children aged $8-10$ years is the number of people in a population waho have dental caries. Purpose: the purpose of this study to know the prevalence of first molar permanent caries in children aged $8-10$ years in Elementary School, there are 04 Pagi Pasar Minggu, 05 Pagi Pasar Minggu, Al-Hikman and Darul Mutaqqin in October 2018. Method: the type of this research is observational descriptive. Population of this research are all of the students aged $8-10$ years old. Purposive sampling is used for sampling method. Result: the results of first permanent molar caries in children aged $8-10$ years have been obtained through objective examination. From 236 samples, there are 944 teeth of first permanent molars and the results have shown that 108 first permanent molar caries in children aged 8 years, 233 molars caries at age 9 years old and 137 molars caries at age 10 years old. Conclusion: from the research that has been done, it can be concluded that the causes of dental caries is still high are lack of knowledge and awareness, both children and parents in maintening oral hygiene.

Keywords: prevalence, first molar permanent, children

\section{PENDAHULUAN}

$\mathrm{K}$ aries gigi merupakan salah satu gangguan kesehatan gigi dan mulut. Karies gigi terjadi gigi yang meliputi enamel, dentin, dan sementum. Proses kerusakan gigi ini dimulai adanya proses demineralisasi yang diikuti kerusakan zat organik sehingga terjadi perkembangan bakteri. ${ }^{1}$ Anak dengan usia 6-14 tahun merupakan usia yang rentan terhadap penyakit gigi dan mulut karena umumnya anak-anak tersebut masih mempunyai perilaku kebiasaan jajan makanan dan minuman baik di sekolah maupun di rumah. ${ }^{1,2}$

Kerusakan gigi semakin meningkat disebabkan faktor makanan/diet yang memicu kerusakan pada gigi seperti minuman bersoda dan permen. Selain 
itu, karbohidrat berperan penting terhadap terjadinya karies pada gigi. Jajanan merupakan salah satu faktor yang mempengaruhi terjadinya karies gigi. Konsumsi makanan kariogenik yang sering dan berulang-ulang akan menyebabkan $\mathrm{pH}$ plak tetap di bawah normal dan menyebabkan demineralisasi enamel tanpa diimbangi dengan remineralisasi, sehingga terjadilah pembentukan karies. ${ }^{3}$ Perilaku dalam menyikat gigi, jenis makanan yang dikonsumsi dan pengetahuan berhubungan erat dengan status kesehatan gigi dan mulut. Pengetahuan yang rendah memiliki risiko terkena penyakit gigi lebih tinggi daripada pengetahuan yang baik. Berdasarkan hasil survei dari Laporan Profil Kesgimul di Indonesia, kurangnya pengetahuan dan pemahaman tentang pemeliharaan kesehatan gigi dan mulut merupakan penyebab tingginya prevalensi karies gigi pada anak usia 6-12 tahun. ${ }^{4}$

Gigi molar satu rahang bawah merupakan gigi tetap yang pertama erupsi pada umur sekitar 6-7 tahun, sehingga menjadi gigi yang paling berisiko terkena karies. Bila gigi tersebut terkena karies, dapat berakibat pencabutan, yang menimbulkan resiko baru seperti perubahan posisi gigi, memengaruhi oklusi, sendi rahang, dan proses mastikasi yang berdampak pada penyerapan nutrisi makanan. ${ }^{5}$ Gigi ini merupakan gigi yang terbesar dan baru erupsi setelah pertumbuhan dan perkembangan rahang sudah cukup memberi tempat untuknya. Gigi geraham pertama permanen berfungsi untuk mengunyah, menumbuk, dan menggiling makanan karena mempunyai permukaan kunyah yang lebar dengan banyak tonjolan-tonjolan dan lekukanlekukan. ${ }^{6}$

\section{METODE}

Jenis penelitian yang digunakan dalam penelitian ini adalah deskriptif observasional. Penelitian ini dilakukan di SDN 04 Pagi Pasar Minggu, SDN 05 Pagi Pasar Minggu, SD Al-Hikmah dan MI Darul Mutaqqin pada bulan Oktober 2018. Populasi yang diteliti pada penelitian ini adalah semua anak sekolah usia 8-10 tahun. Metode pengambilan sampel yang digunakan dalam penelitian ini adalah purposive sampling, pemilihan sampel disesuaikan dengan kriteria-kriteria tertentu yang diterapkan berdasarkan tujuan penelitian.

Kriteria inklusi dalam penelitian ini yaitu hadir di kelas pada saat penelitian dilaksanakan, bersifat kooperatif selama pengambilan data, sehat secara jasmani, gigi molar satu permanen sudah erupsi sempurna. Kriteria eksklusi tidak diizinkan oleh orang tua, memakai alat ortodonti, gigi molar satu permanen tidak tumbuh (tidak mempunyai benih). Pengambilan data yang digunakan adalah data primer yang didapatkan langsung di lapangan pada saat melakukan observasi, pendataan tersebut dicatat langsung ke formulir pemeriksaan.
Pemeriksaan karies gigi molar satu permanen dilakukan di bawah pencahayaan yang baik, kemudian untuk mendeteksi karies gigi pemeriksaan dilakukan dengan kaca mulut dan sonde. Gigi molar satu permanen diperiksa dan dicatat bila mengalami karies. Setelah semua data dari sampel penelitian terkumpul, kemudian dilakukan analisis data deskriptif untuk memberikan deskripsi mengenai subjek penelitian berdasarkan data dari variabel yang diperoleh dari kelompok subjek yang diteliti.

\section{HASIL PENELITIAN}

Penelitian ini dilakukan di SD binaan Puskesmas Kelurahan Jatipadang dan Kelurahan Pasar Minggu 1 yaitu SD Al-Hikmah, MI Darul Mutaqqin, SDN 04 Pagi Pasar Minggu dan SDN 05 Pagi Pasar Minggu. Karakteristik subjek dalam penelitian ini yaitu siswa-siswi yang berumur 8-10 tahun, jumlah populasi pada penelitian ini 243 anak, sampel penelitian yang diteliti ada 236 anak. Hasil penelitian dari distribusi subjek dapat dilihat pada tabel berikut.

Tabel 1. Distribusi Frekuensi Penelitian (N=236)

\begin{tabular}{ccc}
\hline Umur & $\mathbf{n}$ & $\mathbf{\%}$ \\
\hline 8 Tahun & 62 & 26.2 \\
9 Tahun & 98 & 41.5 \\
10 Tahun & 76 & 32.3 \\
\hline Total & $\mathbf{2 3 6}$ & $\mathbf{1 0 0}$ \\
\hline
\end{tabular}

Tabel 1 menunjukkan bahwa subjek penelitain yang paling banyak yaitu pada kelompok umur 9 tahun sebanyak 98 anak (41.5\%). Sedangkan subjek penelitian yang paling sedikit yaitu pada kelompok umur 8 tahun yaitu sebanyak 62 anak (26.2\%).

Tabel 2. Distribusi Frekuensi Berdasarkan Jenis Kelamin $(\mathrm{N}=236)$

\begin{tabular}{llcc}
\hline Jenis Kelamin & & N & \% \\
\hline Laki-Laki & Karies Gigi & 79 & 33.4 \\
& Tidak Karies Gigi & 30 & 12.7 \\
\multirow{2}{*}{ Perempuan } & Karies Gigi & 68 & 28.8 \\
& Tidak Karies Gigi & 59 & 25.1 \\
\hline
\end{tabular}

Tabel 2 menunjukkan bahwa subjek penelitain yang paling banyak ditemukan karies pada gigi molar pertama pemanen yaitu pada laki-laki sebanyak 79 anak (33.4\%). 
Tabel 3. Distribusi Karies Gigi Molar Permanen Pada Anak Umur 8 Tahun

\begin{tabular}{lcc}
\hline $\begin{array}{l}\text { Karies gigi molar pertama } \\
\text { permanen }\end{array}$ & n & \% \\
\hline RA kanan & 13 & 12 \\
RA kiri & 21 & 19.5 \\
RB kanan & 28 & 26 \\
RB kiri & 46 & 42.5 \\
\hline & 108 & 100 \\
\hline
\end{tabular}

Tabel 3 menjelaskan bahwa pada umur 8 tahun yang mengalami karies gigi paling banyak yaitu gigi molar pertama rahang bawah kiri, berjumlah $46(42.5 \%)$ sedangkan yang paling sedikit terkena karies gigi yaitu gigi molar pertama rahang atas kanan dengan jumlah 13 gigi (12\%). Total jumlah karies gigi molar pertama permanen pada anak umur 8 tahun ada 108 gigi.

Tabel 4. Distribusi Karies Gigi Molar Permanen Pada Anak Umur 9 Tahun

\begin{tabular}{lcc}
\hline $\begin{array}{l}\text { Karies gigi molar pertama } \\
\text { permanen }\end{array}$ & n & \% \\
\hline RA kanan & 43 & 19.2 \\
RA kiri & 48 & 20 \\
RB kanan & 68 & 29.1 \\
RB kiri & 74 & 31.7 \\
\hline & 233 & 100 \\
\hline
\end{tabular}

Tabel 4 menjelaskan bahwa pada umur 9 tahun yang mengalami karies gigi paling banyak yaitu gigi molar pertama rahang bawah kiri, berjumlah $74(31.7 \%)$ sedangkan yang paling sedikit terkena karies gigi yaitu gigi molar pertama rahang atas kanan dengan jumlah 43 gigi (19.2\%). Total jumlah karies gigi molar pertama permanen pada anak umur 9 tahun ada 233 gigi.

Tabel 5. Distribusi Karies Gigi Molar Permanen Pada Anak Umur 10 Tahun

\begin{tabular}{lcc}
\hline $\begin{array}{l}\text { Karies gigi molar pertama } \\
\text { permanen }\end{array}$ & n & \% \\
\hline RA kanan & 23 & 16.7 \\
RA kiri & 16 & 13.4 \\
RB kanan & 42 & 29.1 \\
RB kiri & 56 & 40.8 \\
\hline & 137 & 100 \\
\hline
\end{tabular}

Tabel 5 menjelaskan bahwa pada umur 10 tahun yang mengalami karies gigi paling banyak yaitu gigi molar pertama rahang bawah kiri, berjumlah 56 (40.8\%) sedangkan yang paling sedikit terkena karies gigi yaitu gigi molar pertama rahang atas kiri dengan jumlah 16 gigi (13.4\%). Total jumlah karies gigi molar pertama permanen pada anak umur 10 tahun ada 137 gigi.

Tabel 6. Distribusi Frekuensi Penelitian Berdasarkan Tempat penelitian

\begin{tabular}{llcc}
\hline Nama Sekolah & & $\mathbf{n}$ & $\mathbf{\%}$ \\
\hline SDN 04 Pagi & Karies Gigi & 42 & 67 \\
& Tidak Karies Gigi & 21 & 33 \\
\hline SDN 05 Pagi & Karies Gigi & 42 & 73.6 \\
& Tidak Karies Gigi & 15 & 26.4 \\
\hline SD AL-Hikmah & Karies Gigi & 41 & 66 \\
& Tidak Karies Gigi & 21 & 34 \\
\hline MI Darul Mutaqqin & Karies Gigi & 37 & 68 \\
& Tidak Karies Gigi & 17 & 32 \\
\hline
\end{tabular}

Hasil pemeriksaan karies gigi molar pertama permanen pada anak umur 8-10 tahun di SD binaan PUSKESMAS Kelurahan Jatipadang dan Kelurahan Pasar Minggu 1, yaitu SD Al-Hikmah, MI Darul Mutaqqin, SDN 04 Pagi Pasar Minggu dan SDN 05 Pagi Pasar Minggu memiliki jumlah sampel 236 anak.

Tabel 7. Distribusi Frekuensi Karies Gigi Molar Pertama Permanen Pada Anak Umur 8-10 Tahun

\begin{tabular}{cccccc}
\hline \multirow{2}{*}{ Umur } & $\begin{array}{c}\sum \text { M1 } \\
\text { Permanen }\end{array}$ & \multicolumn{2}{c}{$\sum$ Karies } & \multicolumn{2}{c}{$\begin{array}{c}\text { M1Tidak } \\
\text { karies }\end{array}$} \\
\cline { 3 - 6 } & & $\mathbf{n}$ & $\mathbf{\%}$ & $\mathbf{n}$ & $\mathbf{\%}$ \\
\hline 8 tahun & 248 & 108 & 43.5 & 140 & 56.5 \\
9 tahun & 392 & 233 & 59.4 & 159 & 40.6 \\
10 tahun & 304 & 137 & 45 & 167 & 55 \\
\hline
\end{tabular}

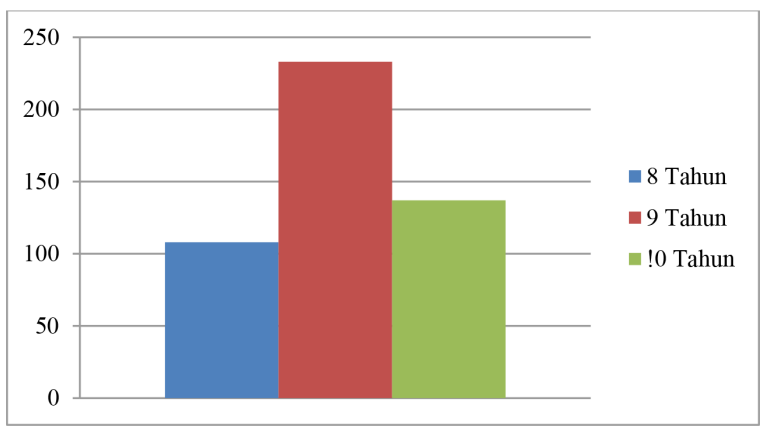

Diagram 1. Distribusi Frekuensi Karies Gigi Molar Pertama Permanen Pada Anak Umur 8-10 Tahun 
Tabel 6 dan diagram 1 menunjukkan data hasil pemeriksaan karies gigi molar pertama permanen pada umur 8-10 tahun yang paling banyak mengalami karies yaitu pada umur 9 tahun berjumlah 233 gigi. Sedangkan yang mengalami karies gigi palig sedikit pada umur 8 tahun yaitu berjumlah 108 gigi. Data dari 236 sampel subjek penelitian memiliki total jumlah karies gigi molar pertama permanen pada anak umur 8-10 tahun di SD binaan PUSKESMAS Kelurahan Jatipadang dan Kelurahan Pasar Minggu 1, yaitu SD Al-Hikmah, MI Darul Mutaqqin, SDN 04 Pagi Pasar Minggu dan SDN 05 Pagi Pasar Minggu, karies gigi yang dapat ditemukan pada gigi molar pertama permanen yaitu sebanyak 478 gigi $(50.6 \%)$ dan gigi yang sehat berjumlah 466 gigi (49.4\%).

\section{PEMBAHASAN}

Penelitian ini dilakukan untuk mengetahui prevalensi karies gigi molar satu permanen di SD binaan Puskesmas Kelurahan Pasar Minggu 1 dan Jati Padang dengan jumlah sampel penelitian sebanyak 236 anak pada rentang umur 8 sampai 10 tahun. Berdasarkan penelitian yang dilakukan menunjukkan bahwa distribusi responden terbanyak yaitu perempuan 127 orang dan laki-laki 109 orang. Anak-anak yang memiliki karies gigi molar satu permanen secara keseluruhan dengan prevalensi mencapai 50,6\%.

Karies gigi adalah salah satu penyakit gigi dan mulut yang terjadi sebagian besar karena gigi tidak dilakukan perawatan sehingga berdampak pada gangguan pertumbuhan dan perkembangan anak. Hal tersebut antara lain, karena kurangnya pemahaman dalam pemeliharaan kesehatan gigi dan mulut. Faktor-faktor yang berperan secara langsung dalam proses karies adalah plak gigi, mikroorganisme, dan pola makan karbohidrat. ${ }^{17}$ Anak umur $8-10$ tahun merupakan satu kelompok yang rentan terhadap penyakit gigi dan mulut karena umumnya anakanak pada umur tersebut masih mempunyai perilaku atau kebiasaan diri yang kurang menunjang terhadap kesehatan gigi. ${ }^{6} \mathrm{Hal}$ tersebut sejalan dengan penelitian yang dilakukan oleh Vineet Dhar dan Maheep Bhatnagar (2009) dimana anak laki-laki lebih banyak terjadi karies daripada anak perempuan. Prevalensi karies yang lebih tinggi pada anak laki-laki dapat dikaitkan dengan kebiasaan makan yang berlebihan dibandingkan anak perempuan. ${ }^{18}$

Berdasarkan penelitian Adhikari dkk (2013) menunjukkan bahwa pada anak umur 8-10 thun sering mengkonsumsi coklat, permen, kue dan lain sebagainya. Makanan tersebut mengandung gula yang sangat tinggi sehingga sisa-sisa makanan di permukaan gigi mampu melekatkan bakteri tertentu dan membuat kondisi mulut menjadi asam. ${ }^{19}$ Konsumsi makanan dan minuman yang mengandung gula secara berulangulang akan menurunkan $\mathrm{pH}$ mulut dengan cepat sampai pada level yang dapat menyebabkan demineralisasi email. Demineralisasi email menyebabkan mineral dalam gigi hilang dan terjadi pengikisan email sehingga memudahkan bakteri masuk dan merusak gigi hingga terjadi karies gigi. Karies tidak menghancurkan gigi dalam hitungan hari atau minggu, melainkan bulan atau tahun. ${ }^{6}$

Data terbaru yang dirilis oleh Oral Health Media Centre pada April 2012, memperlihatkan sebanyak 60-90\% anak usia sekolah dan hampir semua orang dewasa di seluruh dunia memiliki permasalahan gigi. ${ }^{6}$ Perilaku ibu berpengaruh positif terhadap risiko karies pada anak, yaitu semakin buruk perilaku ibu, semakin tinggi risiko karies. Hasil penilitian ini sesuai dengan perilaku sebagian besar ibu (58\%) tidak pernah memberi bekal sekolah pada anaknya, sehingga anak cenderung mengkonsumsi makanan kariogenik yang disediakan di kantin sekolah. Hal tersebut didukung hasil survey pada 94 warung sekolah di SD wilayah Kabupaten Sleman yang menyediakan makanan kariogenik. ${ }^{20}$

Gigi molar satu permanen lebih rentan terhadap karies karena karakteristik morfologi dan fungsinya serta anggapan masyarakat yang masih keliru bahwa gigi molar disamakan dengan gigi sulung yang masih ada penggantinya bila gigi tersebut rusak. ${ }^{22}$ Kurangnya pemahaman masyarakat bahwa pencegahan karies dapat dilakukan sejak dini ini juga mempengaruhi tingginya kejadian karies pada gigi anak, padahal dengan melakukan diet makanan yang mengandung kadar gula yang tinggi dan melakukan pembersihan gigi dengan teratur dapat menekan angka risiko karies pada anak, sehingga kualitas hidup anak menjadi lebih tinggi. ${ }^{5}$ Agar perilaku pemeliharaan kesehatan gigi dapat optimal maka yang perlu dilakukan yaitu biasakan diri untuk menyikat gigi minimal dua kali sehari, yaitu pertama sesudah sarapan dan sebelum tidur di malam hari. Kedua, sebaiknya segera menyikat gigi setelah mengkonsumsi makanan yang manis dan lengket. Ketiga, pilihlah sikat gigi yang mempunyai bulu sikat yang lembut. Banyak orang beranggapan bahwa semakin keras menyikat gigi akan semakin bersih hasilnya. ${ }^{5}$ Peran orangtua dalam pencegahan terjadinya karies pada anak usia sekolah adalah dengan melakukan pemeriksaan rutin ke pelayanan kesehatan gigi. ${ }^{21}$ Pengaruh dari teman sebaya memegang peranan penting dalam sikap anak untuk berkunjung ke dokter gigi, anak akan termotivasi dan meminta orangtuanya untuk mengantar periksa ke dokter gigi, jika mendapat cerita dari teman sebaya bahwa periksa ke dokter gigi itu menyenangkan dan tidak menakutkan. ${ }^{17}$

\section{KESIMPULAN}

Berdasarkan hasil penelitian prevalensi karies gigi molar pertama permanen pada umur 8-10 tahun di SD Binaan Puskesmas Kelurahan Pasar Minggu 1 dan Puskesmas Kelurahan Jatipadang dengan jumlah sampel sebanyak 236 anak menunjukan bahwa yang 
paling banyak mengalami karies yaitu pada umur 9 tahun. Maka dari itu diperlukan program edukasi kesehatan gigi dan mulut melaui program UKGS yang berkesinambungan mengenai pencegahan karies gigi pada usia anak sekolah dasar.

\section{DAFTAR PUSTAKA}

1. Setiari LS, Sulistyowati M. Tindakan Pencegahan Karies Gigi pada Siswa Sekolah Dasar Berdasarkan Teori Health Belief Model. Jurnal Promkes. Surabaya: Departemen Promosi Kesehatan dan Ilmu Perilaku, FKM UNAIR. 2017; 5 (1): 59-70

2. Widodorini T, Rachmawati D, Oktavia D. Hubungan Frekuensi Konsumsi Susu Kemasan dengan Indeks PUFA/pufa Anak Usia 10-11 Tahun di SDN Tunjungsekar 1 Kota Malang. Malang: FKG UB

3. Adrien A. Hubungan Pola Makan dengan Pengalaman Karies pada Siswa SMP Yayasan Perguruan Kristen Andreas Medan. [Skripsi]. Medan: FKG USU. 2017

4. Rama S, Suwargiani AA, Susilawati S. Perilaku anak sekolah dasar daerah tertinggal tentang pemeliharaan kesehatan gigi. Jurnal Kedokteran Gigi. Bandung: FKG UNPAD. 2017; 29(2): 1-9

5. Liwe M, Mintjelungan CN, Gunawan PN. Prevalensi Karies Gigi Molar Satu Permanen pada Anak Umur 6-9 tahun dI Sekolah Dasar Kecamatan Tomohon Selatan. Jurnal e-Gigi. Manado: FKG UNSRAT. 2015; 2 (3): 416-420

6. Silaban S, Gunawan PN, Wicaksono D. Prevalensi Karies Gigi Geraham Pertama Permanen pada Anak Umur 8 - 10 tahun dI SD Kelurahan Kawongkoan Bawah. Manado: FKG UNSRAT

7. Ramayanti, S dan Idral P. Peran Makanan Terhadap Kejadian Karies Gigi. Padang: Jurnal Kesehatan Masyarakat. 2013; 7(2): 89-93.

8. Veiga, N., Daniela A., dkk. Dental Caries: A Review. Portugal: Journal of dental and Oral Health. 2016; 2(5).

9. Yadav, K dan Satyam P. Dental Caries: A Review. Nepal: Asian Journal of Biomedical and Pharmaceutical Sciences. 2016; 6(53): 1-7.

10. Meisida Novita, Oni Soesanto, Heru K C. K-Means Untuk Klasifikasi Penyakit Karies Gigi. Kumpulan Jurnal Ilmu Komputer. 2014; 1(1): 12-22.
11. Iriantoro Dennes Nur Dwi, Candra D, Delvi F. Klasifikasi pada Penyakit Dental Caries Menggunakan Gabungan K-Nearest Neighbor dan Algoritme Genetika. Jurnal Pengembangan Teknologi Informasi dan Ilmu Komputer. 2018; 2(8): 2926-2932.

14. Solikin, Abi Muslihin, Kartinah. Hubungan Tingkat Pengetahuan Orang Tua Tentang Kesehatan Gigi dan Mulut dengan Kejadian Karies Gigi pada Anak Prasekolah di TK 01Pertiwi Karangbangun Karanganyar. Naskah Publikasi Fakultas Ilmu Kesehatan UMS. 2013.

15. Khotimah Khusnul, Suhadi, Purnomo. Faktor-Faktor yang Berhubungan dengan Kejadian Karies Gigi pada Anak Usia 6-12 Tahun di SD N Karangayu Semarang.

16. Ramayanti Sri, Idral P. Peran Makanan Terhadap Kejadian Karies Gigi. Jurnal Kesehatan Masyarakat. 2013; 7(2): 89-93.

17. A’yun Q, Hendrartini J, Supartinah A. Pengaruh keadaan rongga muut, perilaku ibu dan lingkungan terhadap risiko karies pada anak. [Artikel Penelitian]. Majalah Kedokteran Gigi Indonesia. Yogyakarta: FKG UGM. 2016; 2 (2): 86-94

18. Dhar V, Bhatnagar M. Dental caries and treatment needs of children (6-10 tahun) in rural Udaipur, Rajasthan. Indian J Dent Res. India: Departments of Pediatric Dentistry, Darshan Dental College and Hospital, Udaipur, India. 2009

19. Adhikari RB, Malla N, Bhandari PS. Prevalence and treatment needs of dental caries in school-going children attending dental outpatient. Nepal Journal of Medical Sciences. Nepal: Department of a tertiary center in western region in Nepal. 2012; 1 (2): 115-118

20. A'yun Q, Ediati S, Taadi. Survey penyediaan makanan di kantin SD di wilayah Kabupaten Sleman. Laporan penelitian, JKG Poltekkes, Yogyakarta. 2010; 1 - 12

21. Fisher-owens SA, Gansky SA, Platt LJ, Weintraub JA, Soobader MJ, Bramlett MD, Newacheck PW. Influences on children's oral health: conceptual model, American Academy of Pediatrics. 2007: 510-5520.

22. Togoo RA, dkk. Prevalence of first permanent molar caries among 7-10 years old school going boys in Abha city Saudi Arabia. J. Intl Oral Health. Saudi Arabia: Department of Pediatric Dentistry, King Khalid University. 2011; 3 (5): 29-34. 